\title{
Lifetime health outcomes of breast-feeding: a comparison of the policy documents of five European countries
}

\author{
Elena Martin-Bautista', Heather Gage ${ }^{2, *}$, Julia von Rosen-von Hoewel ${ }^{3}$, \\ Viktoria Jakobik ${ }^{4}$, Kirsi Laitinen ${ }^{5}$, Martina Schmid ${ }^{2}$, Jane Morgan ${ }^{2}$, Peter Williams ${ }^{2}$, \\ Tamas Decsi ${ }^{4}$, Cristina Campoy ${ }^{1}$, Berthold Koletzko ${ }^{3}$ and Monique Raats ${ }^{2}$ \\ 'Department of Paediatrics, University of Granada, Granada, Spain: ${ }^{2}$ Food, Consumer Behaviour and Health \\ Research Centre, University of Surrey, Guildford, Surrey, GU2 7XH, UK: ${ }^{3}$ Dr. von Hauner Children's Hospital, \\ Ludwig-Maximilians University, Munich, Germany: ${ }^{4}$ Department of Paediatrics, University of Pécs, Pécs, \\ Hungary: ${ }^{5}$ Functional Foods Forum and Department of Biochemistry and Food Chemistry, University of Turku, \\ Turku, Finland
}

Submitted 5 August 2009: Accepted 10 May 2010: First published online 29 June 2010

\begin{abstract}
Objective: To (i) identify and describe prevailing infant feeding policy documents in five diverse European countries; (ii) analyse types of health outcomes for the infant that are associated with feeding breast milk rather than formula milk in the documents of different countries; and (iii) assess the extent to which documents reflect the WHO global recommendation of exclusive breast-feeding for 6 months. Design: Documentary review and analysis.

Setting: Five geographically dispersed countries of Europe (England, Finland, Germany, Hungary and Spain).

Subjects: Policy documents on infant feeding were identified; statements that linked choice between breast- and formula-feeding to a health outcome for the infant were extracted.

Results: Twenty-six documents (varied authorships, dates, length and character) were identified: four from England; two from Finland; nine from Germany; six from Hungary; and five from Spain. There was no consistency in the way in which health outcomes were cited as factors in the recommendations for breast- rather than formula-feeding. Seven documents contained no reference to the health implications of infant feeding choice. Of 203 statements in remaining documents citing health outcomes, $24 \cdot 1 \%$ mentioned general health effects, $32 \cdot 5 \%$ protection against infections, $31.5 \%$ long-term conditions (e.g. diabetes, CVD) and $11 \cdot 8 \%$ mentioned allergy. Health outcomes were linked to exclusive breast-feeding in only $25 \%$ of statements. Conclusions: Policy documents in the study countries varied in the extent to which they reflect the health outcomes for the baby of breast-feeding, and this may limit effective promotion by health professionals. There is scope to improve the process of bringing evidence and recommendations into policy documents.
\end{abstract}

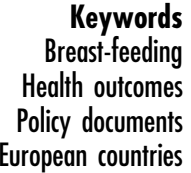

Keywords

Health outcomes

European countries
The feeding of infants and young children is an important area of public health policy ${ }^{(1)}$. Extensive research into the physical, psychological and social implications of breast-feeding (or not breast-feeding) for baby, mother and other family members has resulted in widespread endorsement of breast-feeding as the gold standard ${ }^{(2)}$. Many reasons are advanced in favour of breast-feeding $^{(2-4)}$, and the impact on the health, development and well-being of the baby is central. Infant feeding policies are made by various organisations including international agencies, national and regional governments, professional colleges and associations. Scientific expertise is used to ensure policies are reasonable, justifiable and effective, and to provide accountability and value for money ${ }^{(5,6)}$. The
WHO's global recommendation of exclusive breast-feeding for 6 months is an example of this ${ }^{(7)}$. A systematic review of more than 2000 papers concluded there was no evidence that exclusive breast-feeding for 6 months (compared with exclusive breast-feeding for $4-6$ months) had an adverse effect on growth and development, but that it did have a protective effect against gastrointestinal infections ${ }^{(7)}$.

Policy documents provide guidance for health-care professionals, who are important intermediaries taking the messages of policy-making bodies to consumers. Women, and their partners, have contact with a range of professionals (including nurses, midwives and doctors) before, during and after the birth of their babies, each of whom has the potential to have a significant influence on 
how the parents choose to feed their baby. However, the extent to which available evidence and international recommendations are incorporated in individual policy documents has not been systematically analysed.

Since many mothers perceive comfort and convenience benefits from feeding infant formula ${ }^{(8-10)}$, the health and development advantage for the infant is a major factor in making the case for breast-feeding. Breast milk is a complex natural food containing antibodies, enzymes and hormones ${ }^{(11)}$. Formula milks have not been able to replicate the properties of breast milk perfectly and have been associated with a range of short-term health problems for babies, particularly increased risks for gastric and respiratory infections ${ }^{(2,3,12)}$. The health consequences of not breast-feeding may also extend into late infancy, childhood, adolescence and beyond; for example, the longer-term effects are purported to include elevated risks of obesity, CVD, allergy, type 2 diabetes mellitus and gastrointestinal conditions ${ }^{(2,3,13)}$. In addition, the growing evidence base around the concept of 'programming' suggests that the nutritional environment in the early months of life may 'set' a baby's metabolism with significant lifelong health implications ${ }^{(13,14)}$.

Several recent studies have found low rates of breastfeeding, poor weaning practices and variability within and between nations, and as a result there have been calls for a consistent approach across Europe ${ }^{(15-17)}$. Accordingly, public health policy in the European Union is currently seeking to increase the number of mothers who choose to breast-feed their babies ${ }^{(17-19)}$. In this context, the policy and information environment facing healthcare professionals and the general public plays a strategic role, and thus the findings of the current study are timely.

The present paper reports the findings of a study that investigated how the lifetime health implications for the baby of the choice between breast- and formula-feeding are represented in policy documents in a sample of European countries. The overall aim of the study was to compare the citing of health outcomes in policy documents within and between geographically dispersed European countries with diverse public health nutrition traditions, and to consider the findings in the context of the policy making in Europe. The objectives of the study were to: (i) identify and describe the prevailing infant feeding policy documents in five diverse European countries; (ii) analyse the types of health outcomes for the infant that are associated with feeding breast milk rather than formula milk in the documents of different countries; and (iii) assess the extent to which documents reflect the WHO global recommendation of exclusive breast-feeding for 6 months ${ }^{(7)}$.

\section{Methods}

A search for current policy documents on infant feeding was conducted between July and October 2005 in five
European countries: England, Finland, Germany, Hungary and Spain. The countries were selected to have diverse public health nutrition policy traditions ${ }^{(1)}$ and to represent geographical and cultural spread. We followed established principles of documentary analysis ${ }^{(20,21)}$. A standard operating procedure and coding frame were agreed at the outset to ensure that the study was conducted in the same way in each country, and regular meetings were held and attended by all partners.

Documents were located in each country through an open search, including the Internet, and by targeting the websites of relevant organisations using the following keywords: 'nutrition', 'diet', 'breastfeeding', 'bottle feeding', 'formula feeding', 'weaning', 'complementary feeding', 'infant feeding' and 'baby' (in local languages). Policy documents were retrieved if they contained recommendations or guidelines for health-care professionals about the feeding of healthy infants in the first year of life, and originated from a government body or a professional association. Documents on websites that were not in PDF or HTML format were excluded. Titles of documents were translated into English if necessary, and bibliographic information and a brief description of content were stored in a central database.

The text of each selected document was independently screened by two people in each country and statements that related the choice between feeding breast milk and formula milk to lifetime health outcomes of the baby were extracted. Statements on non-metabolic outcomes, such as tastes or dental caries, and on the effects of malnutrition, nutrient deficiency (e.g. Fe), special maternal diets (e.g. vegan) or maternal micronutrient deficiencies were excluded. When a health outcome was repeated in consecutive sentences, only the first occurrence was included for analysis.

Statements were entered verbatim into a database using the SPSS for Windows statistical software package version $14 \cdot 0$ (SPSS Inc., Chicago, IL, USA), with an English translation, where necessary. Each statement was coded by the type of feeding behaviour to which it referred (exclusive breast-feeding for unspecified time/less than 6 months/ 6 months or more; breast-feeding in general of unspecified duration; formula-feeding) and by health outcome (twenty-two health benefits associated with breast (rather than formula) feeding, grouped into four main categories: health in general; infections; allergy; long-term conditions). Where coding disagreements occurred between the investigators, a third researcher was consulted and the issue was settled through discussion. Use of SPSS facilitated manipulation of the data for the analysis of statements by country, document, type of milk feeding behaviour and health outcome. The number of statements per health outcome, document and country were calculated to allow comparisons. Associations between each of the four main categories of health outcome and the authorship of documents (government $v$. professional 
body) and country were explored using the Mann-Whitney $U$ test and the Kruskal-Wallis test, respectively.

\section{Results}

\section{Policy documents}

All documents identified by the search are listed in the Appendix. They are referred to hereafter by the country letter/document number code shown in the Appendix. The international team reviewed all documents, and a decision was taken to exclude seven from the analysis. Five documents from the English Department of Health were excluded because they were policy proposals or were judged to be about service delivery models and the implementation of policies, rather than recommendations (E5-E9). Two international documents which covered several Spanish-speaking Latin American countries were removed from the Spanish list (S6 and S7) because their content was replicated in the national documents. The Nordic recommendations (F2) were retained in the Finnish list because they were complementary to the internal publication (F1).

Twenty-six policy documents were included in the analysis: four from England, two from Finland, nine from Germany, six from Hungary and five from Spain. Table 1 gives a brief description of each document, authorship and date of publication. The size of each document (number of pages) and the number of references that it contained are also shown. The number of references is used as an indicator of the extent to which the recommendations of each document were evidence-based. There is variation within and between countries in the character of documents, which ranged from being substantial evidence-based reviews (e.g. E1 and F2) to concise summaries (e.g. G2 and H5).

National governments dominated the policy arena in England and Finland. In these countries the search identified substantial expert reports providing the background and evidence-based recommendations for health-care professionals (E1, E2, F1 and F2). In England, two summary documents in support of the WHO global recommendation of exclusive breast-feeding for 6 months ${ }^{(7)}$ were also available (E3 and E4). In Germany, Hungary and Spain, most guidance for frontline health-care staff is provided by professional associations. Documents in Hungary tended to be shorter, and not to cite references in support of recommendations. All documents except two in Hungary and one in England had been published in the five years prior to the study. A main policy document was identifiable in four countries (E3, F1, H3 and S3), but in Germany all documents exist in parallel.

\section{Statements about the bealth outcomes for baby of breast- v. formula-feeding}

A total of 203 statements about the health implications for the baby of the choice between breast- and formulafeeding were extracted from the policy documents that were included in the study. Seven of the policy documents that were identified contained no such statements (two produced by professional associations: $\mathrm{E} 4$ and $\mathrm{H} 2$; three by regional governments: G3, G4 and G5; two by national governments: G8 and G9). The distribution of statements across the four main categories and twentytwo separate types of health outcome is shown in Table 2. The representation of individual health outcomes varied between documents, both within and between countries. Most statements referred to protection afforded by breastfeeding against infections (32.5\% of all statements) and longer-term conditions $(31 \cdot 5 \%)$. About a quarter of statements referred to the general health benefits of breastfeeding (compared with formula) and about an eighth to protection against allergy. Considering only those documents containing any health outcome statements, those from Germany and Finland had the highest number of statements per document and Hungary had the lowest.

Generic statements about the health benefits of breastfeeding compared with formula-feeding ( $n$ 49) were most common in Finnish documents $(5.0$ statements per document $v$. mean of $2 \cdot 4$ for the other four countries), and effects on neurological and mental development were the most frequently cited advantages in this group ( $n 19,38 \cdot 8 \% v \cdot n 10,20 \cdot 4 \%$ for each of the other outcomes). Statements that referred to reduced risk of infection ( $n$ 66) mainly concerned the protection provided by breast-feeding against gastrointestinal ( $n$ 16, $24 \cdot 2 \%)$ and respiratory/chest infections ( $n$ 15, 22.7\%). All documents in England and Finland mentioned gastric infections, but this was not the case in the other three countries. Infection was mentioned less in documents from Hungary ( 1.6 statements per document) than in those of other countries (mean of $4 \cdot 0$ ). The protection afforded by breast-feeding against allergy was mostly presented in general terms (fourteen (58.3\%) of twentyfour statements). Reduced allergy risk was often linked to exclusive breast-feeding (although required duration was not usually stated) and familial history of atopy (data not shown). Protection against gastrointestinal conditions, such as Crohn's disease, irritable bowel syndrome and ulcerative colitis, were most frequently mentioned among the long-term conditions (twenty-one $(32 \cdot 8 \%)$ of sixty-four statements). There were no statements in any documents about the effect of milk feeding choice on bone health. Exemplar statements for each category of outcome are shown in the Table 3. Outcomes were often simply expressed, without explanation or reference to the evidence base.

Taking all countries together and including all documents, there were no significant differences in the representation of the four main categories of health outcome between documents produced by government agencies and professional associations. Similarly, there were no significant differences in the representation of health outcome categories across countries (data not shown). 
Table 1 Policy documents on infant feeding in five European countries (bibliographic details of all documents are given in the Appendix)

\begin{tabular}{|c|c|c|c|c|c|c|c|}
\hline \multirow[b]{2}{*}{ Country } & \multirow[b]{2}{*}{ Study no. } & \multirow[b]{2}{*}{ Date } & \multicolumn{2}{|l|}{ Author } & \multirow[b]{2}{*}{ Brief description of document } & \multicolumn{2}{|c|}{ Number of } \\
\hline & & & Name & Type & & Pages & References \\
\hline \multirow[t]{4}{*}{ England } & E1 & 1994 & Department of Health & National government & Expert review and recommendations on weaning & 124 & 261 \\
\hline & E2 & 2002 & Department of Health & National government & $\begin{array}{l}\text { Review of welfare foods for government by scientific } \\
\text { committee }\end{array}$ & 147 & 307 \\
\hline & E3 & 2003 & Department of Health & National government & Recommendation on infant feeding for health professionals & 4 & 25 \\
\hline & E4 & 2004 & Royal College of Midwives & Professional association & Position statement on breast feeding (endorses WHO 2001) & 2 & 6 \\
\hline \multirow[t]{2}{*}{ Finland } & $\mathrm{F} 1$ & 2004 & $\begin{array}{l}\text { Ministry of Social Affairs and Health, } \\
\text { Helsinki }\end{array}$ & National government & $\begin{array}{l}\text { Dietary recommendations for pregnant and lactating women, } \\
\text { infants and toddlers }\end{array}$ & 254 & 43 \\
\hline & $\mathrm{F} 2$ & 2004 & Nordic Council of Ministers, Copenhagen & $\begin{array}{l}\text { Cross-national government } \\
\text { agency }\end{array}$ & $\begin{array}{l}\text { Scientific background and basis for the nutrition } \\
\text { recommendations in individual Nordic countries }\end{array}$ & 436 & $\begin{array}{l}1721 \text { ( } 153 \text { on } \\
\text { breast-feeding) }\end{array}$ \\
\hline \multirow[t]{9}{*}{ Germany } & G1 & 2000 & $\begin{array}{l}\text { German League for the Child, Family } \\
\text { and Society }\end{array}$ & $\begin{array}{l}\text { Professional association } \\
\text { (consortium) }\end{array}$ & Basic instructions for health professionals on infant nutrition & 7 & 24 \\
\hline & G2 & 2000 & $\begin{array}{l}\text { German Society for Paediatric and } \\
\text { Adolescent Medicine }\end{array}$ & Professional association & $\begin{array}{l}\text { Overview for health professionals of different infant feeding } \\
\text { possibilities }\end{array}$ & 2 & 0 \\
\hline & G3 & 2000 & Research Institute for Child Nutrition & Regional government & $\begin{array}{l}\text { Scientifically based policy document for health-care } \\
\text { professionals }\end{array}$ & 7 & 0 \\
\hline & G4 & 2000 & Research Institute for Child Nutrition & Regional government & $\begin{array}{l}\text { Advice for health professionals on best feeding options if } \\
\text { breast-feeding is not possible }\end{array}$ & 5 & 0 \\
\hline & G5 & 2000 & Research Institute for Child Nutrition & Regional government & $\begin{array}{l}\text { Advice for health professionals on steps from milk feeding to } \\
\text { solid food }\end{array}$ & 4 & 0 \\
\hline & G6 & 2001 & Research Institute for Child Nutrition & Regional government & $\begin{array}{l}\text { Nutrition recommendations and transition from milk feeding to } \\
\text { solid food }\end{array}$ & 7 & 18 \\
\hline & G7 & 2001 & Federal Centre for Health Education & National government & $\begin{array}{l}\text { Breast-feeding recommendations for health professionals and } \\
\text { consumers }\end{array}$ & 10 & 26 \\
\hline & G8 & 2001 & Federal Centre for Health Education & National government & $\begin{array}{l}\text { Advice for health professionals on the nutritional aspects of } \\
\text { breast-feeding }\end{array}$ & 7 & 24 \\
\hline & G9 & 2004 & National Breastfeeding Committee & National government & Policy recommendations on the duration of breast-feeding & 2 & 7 \\
\hline \multirow[t]{5}{*}{ Hungary } & $\begin{array}{l}\mathrm{H} 1 \\
\mathrm{H} 2\end{array}$ & $\begin{array}{l}1997 \\
1998\end{array}$ & $\begin{array}{l}\text { National Institute for Paediatric Health } \\
\text { Professional Association of Obstetrics } \\
\text { and Gynaecology }\end{array}$ & $\begin{array}{l}\text { National government } \\
\text { Professional association }\end{array}$ & $\begin{array}{l}\text { Concise summary of infant feeding recommendations } \\
\text { Concise summary about vitamin and mineral supplementation } \\
\text { for professionals in obstetric care }\end{array}$ & $\begin{array}{l}2 \\
2\end{array}$ & $\begin{array}{l}0 \\
0\end{array}$ \\
\hline & H3 & 2000 & Hungarian Dietetic Association & Professional association & $\begin{array}{l}\text { Detailed summary of the basic aspects of nutrition in the } \\
\text { paediatric age groups }\end{array}$ & 24 & 0 \\
\hline & $\mathrm{H} 4$ & 2001 & $\begin{array}{l}\text { Professional Association of Paediatric } \\
\text { Medicine }\end{array}$ & Professional association & $\begin{array}{l}\text { Official opinion of the Hungarian paediatric association on } \\
\text { infant nutrition }\end{array}$ & 14 & 0 \\
\hline & H5 & 2004 & Hungarian Association of Midwives & Professional association & Summary of position of midwifes' association on infant feeding & 2 & 0 \\
\hline & $\mathrm{H} 6$ & 2004 & Hungarian Association for Breastfeeding & Professional association & Practical aspects of breast-feeding & 35 & 0 \\
\hline \multirow[t]{5}{*}{ Spain } & S1 & 2001 & $\begin{array}{l}\text { Breastfeeding Committee of the Spanish } \\
\text { Association of Paediatrics }\end{array}$ & Professional association & $\begin{array}{l}\text { Latest evidence about advantages of breast-feeding for } \\
\text { paediatricians }\end{array}$ & 6 & 25 \\
\hline & S2 & 2004 & $\begin{array}{l}\text { Breastfeeding Committee of the Spanish } \\
\text { Association of Paediatrics }\end{array}$ & Professional association & $\begin{array}{l}\text { Breast-feeding guidelines for paediatricians and other health } \\
\text { professionals }\end{array}$ & 439 & 48 \\
\hline & S3 & 2001 & $\begin{array}{l}\text { Spanish Society of Gastroenterology, } \\
\text { Hepatology and Paediatric Nutrition }\end{array}$ & Professional association & $\begin{array}{l}\text { Nutrition guidelines and advantages of breast-feeding for } \\
\text { health professionals }\end{array}$ & 4 & 10 \\
\hline & S4 & 2004 & $\begin{array}{l}\text { Spanish Association of Primary Care } \\
\text { Paediatricians }\end{array}$ & Professional association & $\begin{array}{l}\text { Guidance for primary care paediatricians on breast-feeding } \\
\text { in the first year }\end{array}$ & 23 & 57 \\
\hline & S5 & 2004 & $\begin{array}{l}\text { Spanish Society of Family and Community } \\
\text { Medicine }\end{array}$ & Professional association & $\begin{array}{l}\text { Advice to give to mothers on preventive activities in childhood } \\
\text { and adolescence }\end{array}$ & 57 & $\begin{array}{c}42 \text { ( } 17 \text { on } \\
\text { breast-feeding) }\end{array}$ \\
\hline
\end{tabular}


Table 2 Number of statements about the lifelong health outcomes for baby of breast $\left(v\right.$. formula) feeding in nineteen policy documents ${ }^{*}$ from five European countries

\begin{tabular}{|c|c|c|c|c|c|c|c|c|c|c|c|c|c|c|c|c|c|c|c|c|c|c|c|c|c|c|c|c|c|c|}
\hline \multirow[b]{2}{*}{ Document number and authorship } & \multicolumn{5}{|c|}{ England } & \multicolumn{4}{|c|}{ Finland } & \multicolumn{6}{|c|}{ Germany } & \multicolumn{7}{|c|}{ Hungary } & \multicolumn{7}{|c|}{ Spain } & \multirow[b]{2}{*}{$\begin{array}{c}\text { Total (\% total } \\
\text { statements) }\end{array}$} \\
\hline & $\begin{array}{l}1 \\
G\end{array}$ & $\begin{array}{l}2 \\
\mathrm{G}\end{array}$ & $\begin{array}{l}3 \\
\mathrm{G}\end{array}$ & All & $S / D$ & $\begin{array}{l}1 \\
\mathrm{G}\end{array}$ & $\begin{array}{l}2 \\
\mathrm{G}\end{array}$ & All & & $\begin{array}{l}1 \\
P\end{array}$ & $\begin{array}{l}2 \\
P\end{array}$ & $\begin{array}{l}6 \\
\mathrm{R}\end{array}$ & $\begin{array}{l}7 \\
\mathrm{G}\end{array}$ & All & $S / D$ & $\begin{array}{l}1 \\
\mathrm{G}\end{array}$ & $\begin{array}{l}3 \\
\mathrm{P}\end{array}$ & $\begin{array}{l}4 \\
\mathrm{P}\end{array}$ & $\begin{array}{l}5 \\
\mathrm{P}\end{array}$ & $\begin{array}{l}6 \\
\mathrm{P}\end{array}$ & All & $S / D$ & $\begin{array}{l}1 \\
\mathrm{P}\end{array}$ & $\begin{array}{l}2 \\
\mathrm{P}\end{array}$ & $\begin{array}{l}3 \\
\mathrm{P}\end{array}$ & $\begin{array}{l}4 \\
\mathrm{P}\end{array}$ & $\begin{array}{l}5 \\
\mathrm{P}\end{array}$ & All & $S / D$ & \\
\hline \multicolumn{31}{|c|}{ General health benefits of breast-feeding for baby } \\
\hline General statement & 1 & 1 & 0 & 2 & & 0 & 1 & 1 & & 1 & 0 & 0 & 1 & 2 & & 0 & 0 & 1 & 0 & 0 & 1 & & 2 & 0 & 0 & 1 & 1 & 4 & & 10 \\
\hline Nutrient composition & 1 & 0 & 1 & 2 & & 2 & 0 & 2 & & 1 & 0 & 0 & 5 & 6 & & 0 & 0 & 0 & 0 & 0 & 0 & & 0 & 0 & 0 & 0 & 0 & 0 & & 10 \\
\hline Growth/development & 0 & 0 & 1 & 1 & & 0 & 1 & 1 & & 0 & 0 & 0 & 2 & 2 & & 1 & 0 & 1 & 0 & 0 & 2 & & 0 & 2 & 0 & 1 & 1 & 4 & & 10 \\
\hline Mental/neurological & 0 & 1 & 1 & 2 & & 4 & 2 & 6 & & 1 & 0 & 2 & 2 & 5 & & 0 & 0 & 1 & 0 & 3 & 4 & & 1 & 0 & 0 & 1 & 0 & 2 & & 19 \\
\hline All & 2 & 2 & 3 & 7 & $2 \cdot 3$ & 6 & 4 & 10 & $5 \cdot 0$ & 3 & 0 & 2 & 10 & 15 & $3 \cdot 75$ & 1 & 0 & 3 & 0 & 3 & 7 & $1 \cdot 4$ & 3 & 2 & 0 & 3 & 2 & 10 & $2 \cdot 0$ & $49(24 \cdot 1 \%)$ \\
\hline
\end{tabular}

Protective effect of breast-feeding against infections

\begin{tabular}{|c|c|c|c|c|c|c|c|c|c|c|c|c|c|c|c|c|c|c|c|c|c|c|c|c|c|c|c|c|c|c|}
\hline Gastrointestinal & 1 & 1 & 2 & 4 & & 1 & 1 & 2 & & 1 & 0 & 0 & 3 & 4 & & 0 & 0 & 0 & 0 & 1 & 1 & & 3 & 0 & 0 & 2 & 0 & 5 & & 16 \\
\hline Respiratory/chest & 1 & 2 & 2 & 5 & & 0 & 1 & 1 & & 1 & 0 & 0 & 3 & 4 & & 0 & 0 & 1 & 0 & 1 & 2 & & 3 & 0 & 0 & 0 & 0 & 3 & & 15 \\
\hline Ear/otitis media & 0 & 1 & 0 & 1 & & 0 & 1 & 1 & & 1 & 0 & 0 & 2 & 3 & & 0 & 0 & 0 & 0 & 1 & 1 & & 3 & 0 & 0 & 1 & 0 & 4 & & 10 \\
\hline Meningitis & 0 & 1 & 0 & 1 & & 0 & 0 & 0 & & 1 & 0 & 0 & 2 & 3 & & 0 & 0 & 1 & 0 & 0 & 1 & & 2 & 0 & 0 & 0 & 0 & 2 & & 7 \\
\hline Urinary & 0 & 0 & 1 & 1 & & 0 & 0 & 0 & & 1 & 0 & 0 & 2 & 3 & & 0 & 0 & 1 & 0 & 0 & 1 & & 1 & 0 & 0 & 0 & 0 & 1 & & 6 \\
\hline General/unspecified & 0 & 0 & 0 & 0 & & 1 & 1 & 2 & & 2 & 0 & 1 & 1 & 4 & & 0 & 0 & 0 & 1 & 1 & 2 & & 1 & 0 & 2 & 0 & 1 & 4 & & 12 \\
\hline All & 2 & 5 & 5 & 12 & $4 \cdot 0$ & 2 & 4 & 6 & $3 \cdot 0$ & 7 & 0 & 1 & 13 & 21 & $5 \cdot 25$ & 0 & 0 & 3 & 1 & 4 & 8 & $1 \cdot 6$ & 13 & 0 & 2 & 3 & 1 & 19 & $3 \cdot 8$ & $66(32 \cdot 5 \%)$ \\
\hline
\end{tabular}

Protective effect of breast-feeding for allergy

\begin{tabular}{|c|c|c|c|c|c|c|c|c|c|c|c|c|c|c|c|c|c|c|c|c|c|c|c|c|c|c|c|c|c|c|}
\hline Wheeze/asthma & 0 & 3 & 0 & 3 & & 0 & 1 & 1 & & 0 & 0 & 0 & 0 & 0 & & 0 & 0 & 0 & 0 & 0 & 0 & & 0 & 0 & 0 & 0 & 0 & 0 & & 4 \\
\hline Rhinitis & 0 & 0 & 0 & 0 & & 0 & 1 & 1 & & 0 & 0 & 0 & 0 & 0 & & 0 & 0 & 0 & 0 & 0 & 0 & & 0 & 0 & 0 & 0 & 0 & 0 & & 1 \\
\hline Atopic dermatitis & 0 & 0 & 0 & 0 & & 0 & 0 & 0 & & 0 & 0 & 0 & 0 & 0 & & 0 & 0 & 0 & 0 & 0 & 0 & & 4 & 0 & 0 & 0 & 0 & 4 & & 4 \\
\hline Food & 0 & 0 & 0 & 0 & & 0 & 0 & 0 & & 0 & 0 & 0 & 0 & 0 & & 0 & 0 & 0 & 0 & 0 & 0 & & 0 & 0 & 0 & 0 & 1 & 1 & & 1 \\
\hline General/unspecified & 2 & 0 & 1 & 3 & & 1 & 0 & 1 & & 2 & 1 & 1 & 0 & 4 & & 1 & 1 & 1 & 0 & 1 & 4 & & 1 & 0 & 0 & 1 & 0 & 2 & & 14 \\
\hline All & 2 & 3 & 1 & 6 & $2 \cdot 0$ & 1 & 2 & 3 & 1.5 & 2 & 1 & 1 & 0 & 4 & $1 \cdot 0$ & 1 & 1 & 1 & 0 & 1 & 4 & $0 \cdot 8$ & 5 & 0 & 0 & 2 & 0 & 7 & $1 \cdot 4$ & $24(11.8 \%)$ \\
\hline
\end{tabular}

All

Reduced risk of long-term conditions

\begin{tabular}{|c|c|c|c|c|c|c|c|c|c|c|c|c|c|c|c|c|c|c|c|c|c|c|c|c|c|c|c|c|c|c|}
\hline Immune function & 0 & 0 & 0 & 0 & & 1 & 1 & 2 & & 1 & 0 & 0 & 4 & 5 & & 0 & 0 & 0 & 0 & 1 & 1 & & 3 & 0 & 0 & 0 & 0 & 3 & & 11 \\
\hline Gastrointestinal & 2 & 1 & 0 & 3 & & 0 & 1 & 1 & & 4 & 0 & 1 & 1 & 6 & & 0 & 0 & 3 & 1 & 0 & 4 & & 4 & 0 & 0 & 2 & 1 & 7 & & 21 \\
\hline Obesity & 0 & 1 & 1 & 2 & & 0 & 1 & 1 & & 0 & 0 & 1 & 1 & 2 & & 1 & 1 & 0 & 0 & 1 & 3 & & 1 & 0 & 0 & 0 & 0 & 1 & & 9 \\
\hline Diabetes & 0 & 0 & 1 & 1 & & 0 & 1 & 1 & & 1 & 0 & 1 & 1 & 3 & & 1 & 0 & 1 & 0 & 1 & 3 & & 2 & 0 & 0 & 1 & 1 & 4 & & 12 \\
\hline Cardiovascular & 0 & 1 & 0 & 1 & & 0 & 1 & 1 & & 0 & 0 & 0 & 1 & 1 & & 1 & 0 & 0 & 0 & 1 & 2 & & 0 & 0 & 0 & 0 & 0 & 0 & & 5 \\
\hline Cancer & 0 & 0 & 0 & 0 & & 0 & 1 & 1 & & 1 & 0 & 0 & 1 & 2 & & 0 & 0 & 0 & 0 & 0 & 0 & & 2 & 0 & 0 & 1 & 0 & 3 & & 6 \\
\hline All & 2 & 3 & 2 & 7 & $2 \cdot 3$ & 1 & 6 & 7 & $3 \cdot 5$ & 7 & 0 & 3 & 9 & 19 & $4 \cdot 75$ & 3 & 1 & 4 & 1 & 4 & 13 & $2 \cdot 6$ & 12 & 0 & 0 & 4 & 2 & 18 & $3 \cdot 6$ & $64(31.5 \%)$ \\
\hline otal & 8 & 13 & 11 & 32 & $10 \cdot 6$ & 10 & 16 & 26 & $13 \cdot 0$ & 19 & 1 & 7 & 32 & 59 & $14 \cdot 8$ & 5 & 2 & 11 & 2 & 12 & 32 & $6 \cdot 4$ & 33 & 2 & 2 & 12 & 5 & 54 & $10 \cdot 8$ & 203 \\
\hline
\end{tabular}

Authorship: $G=$ national government; $R=$ regional government; $P=$ professional association; $S / D=$ statements per document.

'Seven policy documents containing no health outcome statements were excluded. 
Table 3 Examples of statements in policy documents from five European countries

\begin{tabular}{|c|c|}
\hline Health outcome & Examples of statements \\
\hline General & $\begin{array}{l}\text { 'Breastfed babies are less likely to become ill than those who are bottle fed' (E1) } \\
\text { 'Breastmilk offers numerous preventive advantages' (G1) } \\
\text { 'Breastfeeding improves the health of the baby' (S4) } \\
\text { 'Breastmilk is the ideal nutrition of the young infant in relation to composition and digestibility' (G7) } \\
\text { 'Breastmilk protein is well absorbed and ideal for infants' (F1) } \\
\text { 'Many studies indicate an effect of breastfeeding on healthy neurological development of the infant' (F2) } \\
\text { 'Breastmilk increases development of the brain' (H6) } \\
\text { 'Breastfed children have higher IQ than formula fed' (S1) }\end{array}$ \\
\hline Infection & $\begin{array}{l}\text { 'Breastfeeding protects against infection' (S2) } \\
\text { 'Breast milk protects against infections' (F2) } \\
\text { 'Breastmilk offers numerous preventive advantages' (G1) } \\
\text { 'Breastfed babies are less likely to develop gastric, respiratory and urinary infections' (E3) } \\
\text { '... differences in morbidity between breastfed and non-breastfed infants are small but recognisable for the following } \\
\text { infectious diseases: diarrhoea, bronchopulmonary infection, otitis media, bacterial meningitis, urinary infection...' (G1) } \\
\text { 'Breastmilk decreases risk of respiratory infection' (H4) } \\
\text { 'Breast fed babies have decreased risk of urinary infection' (H4) } \\
\text { 'Breast fed babies have decreased risk of diarrhoea' (H4) } \\
\text { 'The development of bacterial meningitis is less in breastfed babies' (H4) }\end{array}$ \\
\hline Allergy & $\begin{array}{l}\text { 'Breast fed babies have decreased risk of allergy' (H4) } \\
\text { 'Breast fed babies are less likely to develop atopic disease' (E3) } \\
\text { 'Exclusive breast feeding is associated with significant reductions in wheezing' (E3) } \\
\text { 'Exclusive breast feeding during the first months of life is associated with lower asthma rates during childhood' (F2) } \\
\text { 'Breastfeeding decreases risk of atopic dermatitis in new borns' (S1) }\end{array}$ \\
\hline Long-term & $\begin{array}{l}\text { 'Breastfeeding has been associated with lower blood pressure in children and adolescents' (F2) } \\
\text { 'Some studies suggest that breast feeding protects against inflammatory bowel disease and malignant lymphoma' (F2) } \\
\text { '... long term advantages for former breastfed infants ... decreased incidence rate of diabetes mellitus type 1, Crohn's } \\
\text { disease' (G6) } \\
\text { 'Breast fed babies have decreased risk of ulcerative colitis' (H4) } \\
\text { 'The risk of juvenile diabetes is lower in breast fed babies' (H4) } \\
\text { 'Breast feeding decreases the risk of obesity' (H6) } \\
\text { 'Breastfeeding has a protective effect against leukemia' (S4) }\end{array}$ \\
\hline
\end{tabular}

\section{Representation of the WHO global recommendation of exclusive breast-feeding for 6 months ${ }^{(7)}$}

Most of the health outcome statements ( $n$ 152, $74.9 \%$ ) did not specify whether the health effect was dependent on the duration of breast-feeding or exclusivity. Twentyone (10.3\%) statements in eight documents (E2, E3, F2, G1, G2, G7, H1 and S1) attributed a health outcome to exclusive breast-feeding, of which twelve did not specify the necessary duration, one stated a period less than 4 months, one stated a period of 4-6 months, and seven (in line with the WHO recommendation ${ }^{(7)}$ ) referred to exclusive breast-feeding for 6 months or more. The statements that advocated exclusive breast-feeding for less than 6 months, or for an unspecified period, cited a variety of health outcome reasons: generic benefits in health ( $n 1)$ and protection against asthma/wheeze $(n 4)$, gastrointestinal infections ( $n$ 2), respiratory/chest infections ( $n$ 2), diabetes ( $n$ 2), obesity ( $n 1)$ and high blood pressure ( $n$ 2).

Eleven of the twenty-six policy documents that were included in the analysis were published after the release of the WHO global recommendation (2001), but only the English infant feeding recommendations from the Department of Health (E3) referred in any detail to this evidence (in five statements). The other two statements that referred to exclusive breast-feeding for 6 months were in two earlier German documents (G1 and G2). Both of these statements promoted exclusive breastfeeding for 6 months as a means to reduce the risk of allergy, for which the WHO review ${ }^{(7)}$ found no evidence in favour of breast-feeding. The Association for Midwives in England (E4) endorsed the WHO recommendations ${ }^{(7)}$, but their brief position statement did not provide a summary of the evidence base for their members.

\section{Discussion}

The present study found that current documents on infant feeding policies in five European countries vary in authorship, date of publication, length and character. Analysis of the documents showed no consistency in the way in which health outcomes for the baby are cited as factors in the recommendations for breast- rather than formula-feeding. In more than a quarter of the policy documents, health effects of breast-feeding were not mentioned at all, and in the remaining documents they were often described only in general terms. This finding agrees with other recent research which concludes that health risks of feeding infant formula are poorly represented in journal articles ${ }^{(22)}$. The health outcomes most consistently mentioned in policy documents in favour of breast-feeding were in the areas of mental/neurological 
development, protection of immune function, and reduced risk of gastrointestinal and respiratory/chest infections, allergy problems, long-term gastrointestinal conditions and diabetes. Most statements about the health implications of infant feeding choice were not precise about the duration of breast-feeding that is required for benefit, and whether or not the advantage is dependent on exclusive breast-feeding.

Differences between the portfolios of policy documents of individual countries may reflect variations in the structure of health services, resources, history and culture. More substantive policy documents on infant feeding are available in England and Finland, where health care is financed and delivered through public sector arrangements. The greater diversity of agencies producing policy documents on infant feeding in Hungary, Germany and Spain may reflect the more pluralistic nature of their health-care systems. Moreover, professional associations are more important in the policy arena in these countries because maternity and infant services are routinely provided by specialist obstetricians and paediatricians, rather than by general practitioners and primary care teams, as occurs in England and Finland ${ }^{(23-25)}$. In all countries, publication of policy documents on important public health issues such as infant feeding is likely to be the product of some degree of dialogue between government agencies and professional associations.

The search for policy documents and extraction of health outcome statements were conducted carefully and in accordance with a procedure agreed in advance by partners in each country, and researchers met regularly to resolve any issues that arose. However, the study was limited because resource constraints meant the work could be conducted in only five countries. Cross-national comparisons are important because they offer scope for public policy learning ${ }^{(20)}$. Although the sample of countries was chosen to provide diverse public health nutrition policy traditions ${ }^{(1)}$, and a geographical and cultural spread across Europe (West, Scandinavian/Nordic, Central, Eastern, Mediterranean), they may not be representative of all socio-political systems. It is also possible that documents could have been missed by the searches. The analysis of health outcomes is based on counts of statements, but frequencies are not necessarily a good indication of overall significance ${ }^{(20)}$ and should be interpreted with caution. In addition, the study focused on the representation of the health outcomes for the infant of breast (rather than formula) feeding, and statements about maternal outcomes were not covered.

Health-care professionals provide advice and information to consumers, and promote health-enhancing behaviours, within a framework provided by policy documents and guidelines. Although only one of several influences on practice, the format of policy documents has the potential to affect the extent to which professionals understand and transmit recommendations. Professionals may find it difficult to identify key messages in documents which are lengthy and detailed, but may be unable to make a convincing case to consumers if their reference materials do not provide a sufficient explanation and justification of the evidence base for recommendations. Among the countries in the present study, there was striking variation in the presentation and composition of policy documents in circulation. Seven of the documents identified by the search did not mention any health outcomes for the child in support of the feeding recommendation that they promoted. Documents from Hungary tended to be shorter, less likely to cite references in support of recommendations and to contain simpler statements, compared with those of other countries. Statements in the documents of the other countries, and Germany in particular, were more likely to use technical terminology and provide the scientific rationale for recommendations. Some policy documents took the form of detailed expert reviews of the evidence and others were succinct summaries, containing limited or no reference to the scientific basis. Little is known about the role of policy documents in providing a basis for the daily practice of health-care professionals. Research is needed to identify the most effective means of informing health-care professionals about the recommendations of their organisation or professional association and enabling them to communicate meaningful messages to the consumers they serve.

Lack of consistency between documents and countries in the representation of the health outcomes of breast-feeding will limit effective promotion by health professionals ${ }^{(22)}$ and should be a cause for concern among policy makers ${ }^{(26)}$. It may reflect uncertainties in the scientific evidence on the health outcomes associated with infant feeding choices in the developed world. Systematic assessments of the available evidence base show differences in interpretation. While some reviewers endorse the evidence about the protective effect of breast-feeding for diseases like lymphoma, insulin-dependent diabetes mellitus and Crohn's disease $^{(3,11)}$, others adopt a more cautious position ${ }^{(2,27)}$. Although increased susceptibility of non-breast-fed infants to respiratory tract infection and otitis media ${ }^{(27)}$ has been shown to increase health-care costs in the USA ${ }^{(12)}$, other evidence suggests that prolonged breast-feeding does not protect against these illnesses ${ }^{(7)}$. Similar debates exist regarding allergy ${ }^{(28)}$. Recent studies conclude that breastfeeding does not reduce the risk of allergy or asthma ${ }^{(7,29)}$ or that the evidence is equivocal ${ }^{(27)}$, but others suggest an association between increased risk of atopic disease and feeding formula milk ${ }^{(3,30)}$. Given the somewhat speculative status of evidence for some health outcomes, it is perhaps not surprising that there is variation in representation of health outcomes across documents.

The WHO global recommendation of exclusive breastfeeding for 6 months provides another example of how experts can disagree. This is a landmark in infant feeding policy, but only two of the policy documents (both from England) in the five countries in the current study referred 
to it. One explanation for this is that a 4-year lapse of time between the publication of the global recommendation and the search for documents for our study may not have been sufficient for Europe-wide national agencies to consider and adopt the WHO position, and publish new guidelines. Another possible explanation is that some experts do not support the global recommendation unreservedly ${ }^{(2,31)}$, and argue there is no evidence that introducing complementary feeding before 6 months is harmful ${ }^{(32)}$. Thus policy makers would be cautious. Overall, the spirit of the WHO global recommendation is poorly represented: $90 \%$ of statements do not associate health outcomes to exclusive breastfeeding, and many cite protection against varied diseases even though the WHO review found evidence that exclusive breast-feeding for 6 months gave protection only against gastrointestinal infections.

The desirable approach to producing guidelines is through robust synthesis of available evidence and consensus among stakeholders, including practitioners, commissioners and service user representatives ${ }^{(33)}$, and such procedures have been put in place in Australia ${ }^{(34)}$. However, problems exist in moving from research evidence to forming and agreeing policies and recommendations where the evidence not well established, as is the case for infant feeding. Moreover, methodological issues hinder the consolidation of evidence on the health implications of infant feeding choices. Controlled trials to test alternative feeding protocols create ethical dilemmas; problems surround the interpretation of available evidence because of imprecision in the definition of 'breast-feeding' (especially inadequate distinction between 'ever' and 'exclusive' breast-feeding, and failure to report for how long breast-feeding is maintained); studies to monitor long-term health outcomes are difficult to implement and may be affected by a multitude of confounding factors; and epidemiological associations may not be fully explained by a biological mechanism. When decisions are being made under conditions of uncertainty, current practice and contextual factors (such as the influence of local interest groups and the balance of committee membership) may affect final decisions about which health effects of infant feeding choices are represented in documents.

The findings of the present study suggest that there is a scope to synchronise evidence and approaches to policy formulation across Europe and to ensure that recommendations reflect new knowledge. The European Commission's White Paper on governance within the European Union has highlighted the need for greater coherence of policies ${ }^{(35)}$. This includes a commitment to increasing the involvement of stakeholders and consumers in the policy-making process, and to greater openness and transparency in the collection and use of expert advice so it is clear what alternative views exist and from where they have come ${ }^{(35)}$.

Future developments in the area of infant feeding policy are likely to be influenced by output from ongoing research on metabolic programming and the effect of the early nutrition environment on lifelong health. As research findings are disseminated, it is important that policy makers are able to evaluate the scientific evidence and provide clear guidance for health-care professionals about what is known about the lifelong health implications and the associated areas of uncertainty. In this way, consumers will receive full and balanced information on which to make choices about feeding their infant, and public health considerations will be properly addressed.

\section{Acknowledgements}

Source of funding: This study was supported as a part of the European Project 'Early Nutrition Programming-EARNEST' within the 6th Framework Programme (no. FOOD-CT-2005007036), and by the Social Insurance Institution of Finland. Conflict of interest declaration: None. Authors' contributions: H.G., M.R. and J.M. designed the study. C.C., T.D., B.K., K.L. and M.R. managed study sites. All authors contributed to methodological development. V.J., K.L., E.M.-B., M.S. and J.v.R.v.H. undertook data collection and analysis. H.G., J.M., M.R. and P.W. contributed to the analysis. H.G. and E.M.-B. drafted the manuscript, and all authors commented on it.

\section{References}

1. World Health Organization (2006) Comparative Analysis of Nutrition Policies in the WHO European Region. A Comparative Analysis of Nutrition Policies and Plans for Action in WHO European Member States. WHO European Ministerial Conference on Counteracting Obesity, Istanbul, Turkey, 15-17 November 2006. EUR/06/15062700/BD/2. Copenhagen: WHO Regional Office for Europe.

2. American Academy of Pediatrics (2005) Policy statement: Breastfeeding and the use of human milk. Pediatrics 115, 496-506.

3. Lawrence R (1997) A Review of the Medical Benefits and Contraindications to Breastfeeding in the US. Maternal and Child Health Technical Information Bulletin. Washington, DC: US Department of Health and Human Services.

4. Department of Health (2003) Infant Feeding Recommendations. London: Department of Health.

5. Brown MB, Lentsch J, Weingart P (2005). Representation, expertise and the German parliament: a comparison of three advisory institutions. In Democratization of Expertise? Exploring Novel Forms of Scientific Advice in Political Decision Making [S Maasen \& P Weingart, editors]. Sociol Sci 24, 81-100.

6. Rayner S (2007) The rise of risk and decline of politics. Environ Hazards 7, 165-172.

7. World Health Organization (2001) The Optimal Duration of Exclusive Breastfeeding. Geneva: WHO.

8. Murphy E, Parker S \& Phipps C (1998) Competing agendas in infant feeding. Br Food J 100, 128-132.

9. Shaw R, Wallace LM \& Bansal M (2003) Is breast best? Perceptions of infant feeding. Community Pract 76, 299-303.

10. Stewart-Knox B, Gardiner K \& Wright M (2003) What is the problem with breastfeeding? A qualitative analysis of infant feeding perceptions. J Hum Nutr Diet 16, 265-273. 
11. Hoddinott P, Tappin D \& Wright C (2008) Breastfeeding. BMJ 336, 881-887.

12. Weimer J (2001) The Economic Benefits of Breastfeeding: A Review and Analysis. Food Assistance and Nutrition Report no. 13. Washington, DC: US Department of Agriculture.

13. World Health Organization (2007) Evidence of the Longterm Effects of Breastfeeding. Geneva: WHO.

14. Delisle H (2002) Programming of Chronic Disease by Impaired Fetal Nutrition. Geneva: WHO, Department of Nutrition for Health and Development.

15. Cattaneo A, Yngve A, Koletzko B et al. (2005) Protection, promotion and support of breast-feeding in Europe: current situation. Public Health Nutr 8, 39-46.

16. Nichol A, Thayaparan B, Newell M-L et al. (2002) Breastfeeding policy, promotion and practice in Europe. Results of a survey of non-governmental organisations. J Nutr Environ Med 12, 255-264.

17. World Health Organization (2003) Comparative Analysis of Food and Nutrition Policies in WHO European Member States. Copenhagen: WHO Regional Office for Europe.

18. European Commission, Directorate of Public Health and Risk Assessment (2004) Protection, Promotion and Support of Breastfeeding in Europe: A Blueprint for Action. Luxembourg: European Commission.

19. World Health Organization (2007) Proposed Second Action Plan for Food and Nutrition Policy, 2007-2012. Copenhagen: WHO Regional Office for Europe.

20. May T (1993) Social Research. Issues, Methods, Process. Milton Keynes: Open University Press.

21. Dew K (2005) Documentary analysis in CAM research. Part 1. Complement Ther Med 13, 297-302.

22. Smith J, Dunstone M \& Elliott-Rudder M (2009) Health professionals' knowledge of breastfeeding: are the health risks of infant formula feeding accurately conveyed by the titles and abstracts of journal articles? J Hum Lact 25, 350-358.

23. Martin-Moreno J, Alonso P, Claveria A et al. (2009) Spain: a decentralised health system in a constant state of flux. BMJ 338, b1170.
24. Papanicolaou S, Pons ME, Hampel C et al. (2005) Medical resource utilisation and cost of care for women seeking treatment for urinary incontinence in an outpatient setting: examples from three countries participating in the PURE study. Maturitas 52, Suppl. 2, S35-S47.

25. European Observatory on Health Care Systems (2001) Health Care Systems in Transition. Copenhagen: WHO Regional Office for Europe.

26. Alonso-Coello P (2008) Quality of guidelines on obesity in children is worrying. BMJ 337, a2474.

27. Agency of Healthcare Research and Quality (2007) Breastfeeding and Maternal and Infant Health Outcomes in Developed Countries. Washington, DC: Agency of Healthcare Research and Quality.

28. Gahagans S (2007) Breast feeding and the risk of allergy and asthma. BMJ 335, 782-783.

29. Kramer MS, Matush L, Vanilovich I et al. (2007) Effect of prolonged and exclusive breast feeding on risk of allergy and asthma: cluster randomised trial. BMJ 335, 815-820.

30. Silvers KM, Frampton CM, Wickens K et al. (2009) Breastfeeding protects against adverse respiratory outcomes at 15 months of age. Matern Child Nutr 5, 243-250.

31. ESPGHAN Committee on Nutrition and Complementary Feeding (2008) A commentary by the ESPHGAN Committee on Nutrition. J Pediatrics Gastroenterol Nutr 46, 99-110.

32. Raiten D, Kalham SC \& Hay WW (2007) Maternal nutrition and optimal infant feeding practices: executive summary. Am J Clin Nutr 85, Suppl., 577S-583S.

33. Renfrew M, Dyson L, Herbert G et al. (2008) Developing evidence-based recommendations in public health incorporating the views of practitioners, service users and user representatives. Health Expect 11, 3-15.

34. Australian Government, National Health and Medical Research Council (2007) NHMRC Standards and Procedures for Externally Developed Guidelines. Canberra: NHMRC.

35. Commission of the European Communities (2001) European Governance: A White Paper. COM(2001) 428 final. Brussels, 25.7.2001. Brussels: Commission of the European Communities. 
Appendix

\section{List of policy documents identified by the search, and references}

\begin{tabular}{|c|c|c|c|}
\hline Country & $\begin{array}{l}\text { Included/ } \\
\text { excluded }\end{array}$ & Study no. & References \\
\hline \multirow[t]{9}{*}{ England } & \multirow[t]{4}{*}{ Included } & $\mathrm{E} 1$ & $\begin{array}{l}\text { Department of Health (1994) Weaning and the Weaning Diet. Report on Health and Social } \\
\text { Subjects no. 45. London: HMSO. }\end{array}$ \\
\hline & & E2 & $\begin{array}{l}\text { Department of Health (2002) Scientific Review of the Welfare Foods Scheme. Report on Health } \\
\text { and Social Subjects no. 51. London: HMSO. }\end{array}$ \\
\hline & & E3 & Department of Health (2003) Infant Feeding Recommendations. London: HMSO. \\
\hline & & E4 & $\begin{array}{l}\text { Royal College of Midwives (2004) Infant Feeding. Position Statement no. 5. London: Royal } \\
\text { College of Midwives. }\end{array}$ \\
\hline & \multirow[t]{5}{*}{ Excluded } & E5 & Department of Health (2003) Every Child Matters. London: HMSO. \\
\hline & & E6 & Department of Health (2004) Choosing Health: Making Healthy Choices. London: HMSO. \\
\hline & & E7 & Department of Health (2004) Good Practices and Innovation in Breastfeeding. London: HMSO. \\
\hline & & E8 & $\begin{array}{l}\text { Department of Health \& Department for Education and Science (2004) National Service } \\
\text { Framework for Children, Young People and Maternity Services. London: HMSO. }\end{array}$ \\
\hline & & E9 & Department of Health (2005) Choosing a Better Diet: A Food and Health Action Plan. London: HMSO. \\
\hline \multirow[t]{2}{*}{ Finland } & \multirow[t]{2}{*}{ Included } & $\mathrm{F} 1$ & $\begin{array}{l}\text { Ministry of Social Affairs and Health (2004) Lapsi, perhe ja ruoka (Child, Family and Food: } \\
\text { Dietary Recommendation for Pregnant and Lactating Women, Infants and Toddlers). Helsinki: } \\
\text { Ministry of Social Affairs and Health. }\end{array}$ \\
\hline & & $\mathrm{F} 2$ & $\begin{array}{l}\text { Nordic Council of Ministers (2004) Nordic Nutrition Recommendations - Integrating Nutrition ana } \\
\text { Physical Activity. Copenhagen: Nordic Council of Ministers. }\end{array}$ \\
\hline \multirow[t]{9}{*}{ Germany } & \multirow[t]{9}{*}{ Included } & G1 & $\begin{array}{l}\text { Schöch G (2000) Grundsätze der Ernährung von Säuglingen und Kleinkindern (Fundamentals of } \\
\text { infant nutrition). Frühe Kindheit 2, 4-10. }\end{array}$ \\
\hline & & G2 & $\begin{array}{l}\text { Koletzko B \& Müller H (2000) Ernährung im Säuglings-, Kleinkind- und Schulalter (Nutrition in } \\
\text { infant-, toddler- and school age), pp. 1-9. München/Jena: Urban \& Fischer. }\end{array}$ \\
\hline & & G3 & $\begin{array}{l}\text { Kersting M (2000) Die Lebensmittelgesetzgebung der EG und die Kinderernährung in } \\
\text { Deutschland (The food legislation in the EU and child nutrition in Germany, 2000). } \\
\text { Ernährungsumschau 47, 437-441. }\end{array}$ \\
\hline & & G4 & Manz F \& Kersting M (2000) The right milk for non-breastfed infants. Kinderarztl Prax 25, 9. \\
\hline & & G5 & $\begin{array}{l}\text { Kersting M (2000) Complementary food: the healthy nutrition for the } 1 \text { st year of life. Kinderarzt } \\
\text { Praxis } 30,3 .\end{array}$ \\
\hline & & G6 & Kersting M (2001) Nutrition of the healthy infant. Monatsschr Kinderheilkd 149, 4-10. \\
\hline & & G7 & $\begin{array}{l}\text { Przyrembel H (2001) Die Vorteile der Muttermilch (Advantages of Breast Milk. Breastfeeding ana } \\
\text { Breastmilk Nutrition), pp. 13-24. Köln: Bundeszentrale für gesundheitliche Aufklärung. }\end{array}$ \\
\hline & & G8 & $\begin{array}{l}\text { Kersting M (2001) Ernährung der stillenden Mutter und Beikost für das Kind (Nutrition of the } \\
\text { Breastfeeding Mother and Complementary Food for the Child), pp. 198-209. Köln: } \\
\text { Bundeszentrale für gesundheitliche Aufklärung. }\end{array}$ \\
\hline & & G9 & $\begin{array}{l}\text { Nationale Stillkommission Deutschlands (2004) Empfehlungen zur Stilldauer } \\
\text { (Recommendations for the Duration of Breastfeeding). Berlin: Nationale Stillkommission. }\end{array}$ \\
\hline \multirow[t]{6}{*}{ Hungary } & \multirow[t]{6}{*}{ Included } & $\mathrm{H} 1$ & $\begin{array}{l}\text { Országos Csecsemõ és Gyermekegészségügyi Intézet (1997) Mit egyen a baba? (What should } \\
\text { we give a baby to eat?) Csecsemõgondozás 2, 13-14. }\end{array}$ \\
\hline & & $\mathrm{H} 2$ & $\begin{array}{l}\text { Szülészeti és Nõgyógyászati Szakmai Kollégium, Rigó J (1998) Vitamin és ásványianyag } \\
\text { supplementation (Supplementation of Vitamins and Minerals). Budapest: Szülészet } \\
\text { Nögyógyászat: Szülészek Nögyógyászok Egyesülete. }\end{array}$ \\
\hline & & H3 & $\begin{array}{l}\text { Barna M (2000) Táplálkozás csecsemö és gyermekkorban (Nutrition in children and } \\
\text { adolescents), pp. 1-24. Budapest: Magyar Táplálkozástudományi Társaság. }\end{array}$ \\
\hline & & $\mathrm{H} 4$ & $\begin{array}{l}\text { Arató A \& Várkonyi A (2001) Az egészséges csecsemö táplálásának irányelvei (módszertani } \\
\text { ajánlás) (Policy document on healthy infant nutrition). Gyermekgyógyászat 52, 303-316. }\end{array}$ \\
\hline & & H5 & $\begin{array}{l}\text { Országos Bábaszövettség (2004) Tápszerpótlás adása szoptatott babáknak (Formula } \\
\text { complement for breastfed babies). Bábák, Szülésznõk 3, issue 3, 49-50. }\end{array}$ \\
\hline & & $\mathrm{H} 6$ & $\begin{array}{l}\text { Ungváry R (2004) Szoptatós füzet (Pamphlet of Breastfeeding), pp. 1-35. Budapest: Országos } \\
\text { Egészségfejlesztési Intézet. }\end{array}$ \\
\hline \multirow[t]{7}{*}{ Spain } & \multirow[t]{5}{*}{ Included } & S1 & $\begin{array}{l}\text { Comité de Lactancia de la Asociación Española de Pediatría (2001) Hablemos de lactancia } \\
\text { materna. Ultimas evidencias (Let's Talk About Breastfeeding. Latest Evidence). Madrid: } \\
\text { Comité de Lactancia de la AEP. }\end{array}$ \\
\hline & & S2 & $\begin{array}{l}\text { Sociedad Española de Gastroenterología, Hepatología y Nutrición Pediátrica (2001) Guias } \\
\text { prácticas sobre nutrición. Alimentación en el lactante (Nutrition Guidelines. The Feeding of } \\
\text { Breastfed Children). Tenerife: SEGHNP. }\end{array}$ \\
\hline & & S3 & $\begin{array}{l}\text { Comité de Lactancia de la Asociación Española de Pediatría (2004) Lactancia materna: guía } \\
\text { para profesionales (Breastfeeding: Guidelines for Professionals). Madrid: Comité de Lactancia } \\
\text { de la AEP. }\end{array}$ \\
\hline & & S4 & $\begin{array}{l}\text { Asociación Española de Pediatría de Atención Primaria (2004) Lactancia materna y } \\
\text { alimentación durante el primer año de vida (Breastfeeding and Feeding During the First Year } \\
\text { of Life). Madrid: AEPAP. }\end{array}$ \\
\hline & & S5 & $\begin{array}{l}\text { Sociedad Española de Medicina de Familia y Comunitaria (2004) Actividades preventivas en la } \\
\text { infancia y adolescencia (Preventive Activities in Childhood and Adolescence). Barcelona: SEMFYC. }\end{array}$ \\
\hline & \multirow[t]{2}{*}{ Excluded } & S6 & $\begin{array}{l}\text { Pan American Society of Health (2002) Advantages of Breastfeeding. Washington, DC: } \\
\text { Pan American Society of Health. }\end{array}$ \\
\hline & & S7 & $\begin{array}{l}\text { Pan American Society of Health (2006) Guide for Complementary Breastfeeding in Breast Fed } \\
\text { Children. Washington, DC: Pan American Society of Health. }\end{array}$ \\
\hline
\end{tabular}

